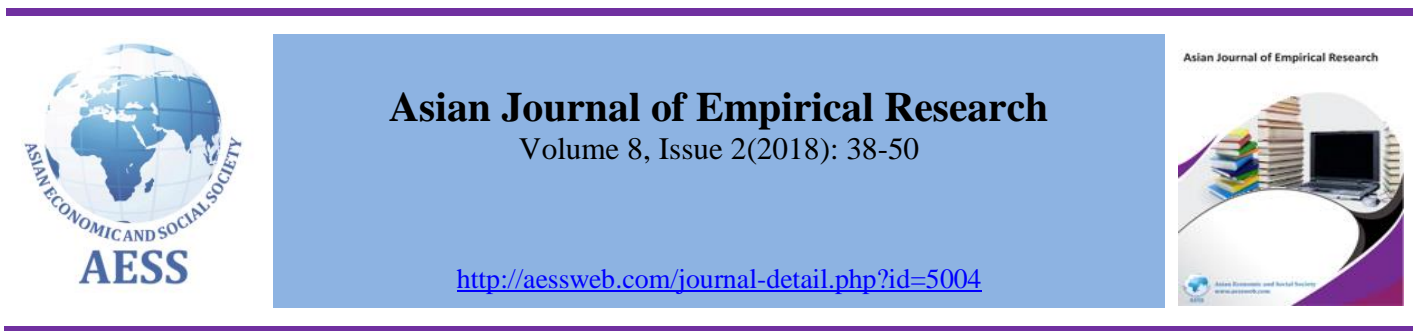

\title{
Residents' satisfaction and support to sustainable tourism development: Evidence from Tra Vinh province, Vietnam
}

\section{Quang Linh Huynh}

Vice Dean; School of Economics and Law, TraVinh University, TraVinh City, Vietnam.

$\checkmark \underline{\text { huynhquanglinh@tvu.edu.vn }}$

ARTICLE HISTORY:

Received: $15-$ Sep-2017

Accepted: 06-Jan-2018

Online available: 22-Jan-2018

\section{Keywords:}

Tourism development, Economic sustainability, Environmental sustainability, Socio-cultural sustainability

\begin{tabular}{l}
\hline ABS TRACT \\
This research attempts to evaluate local residents' satisfaction and \\
support to the development of tourism through economic, \\
environmental and socio-cultural sustainability of tourism. The data \\
was collected with a survey of local residents in Tra Vinh province \\
of Vietnam. The empirical findings demonstrate that local \\
residents' perceived economic, environmental and socio-cultural \\
sustainability affects both their satisfaction and support to tourism \\
development in the locality. The sustainability of socio-culture is \\
most concerned by local residents. The greatest importance is, this \\
research discussed and offered statistical evidence on the mediating \\
role of local residents' satisfaction with the development of tourism \\
in the effect of perceived economic, environmental and socio- \\
cultural sustainability on local residents' support to the \\
development of local tourism. The current study is expected to \\
provide tourism managers with a better understanding of the \\
complicated links among economic, environmental, socio-cultural \\
sustainability, local residents' satisfaction and their support to \\
tourism development. Therefore, they should pay more attention to \\
tourism satisfaction of local community in order to enhance host \\
residents' support to the development of local tourism.
\end{tabular}

\section{Contribution/ Originality}

This is first study that discuss and provide statistical support for the mediating effect of local residents' satisfaction on the relationship between their support to tourism development and perceived sustainability, focusing on economic, environmental and socio-cultural sustainability. The effect of perceived sustainability of tourism on local residents' support for tourism development is contingent on their satisfaction with tourism development.

DOI: 10.18488/journal.1007/2018.7.2/1007.2.38.50

ISSN (P): 2306-983X, ISSN (E): 2224-4425

How to cite: Quang Linh Huynh (2018). Residents' satisfaction and support to sustainable tourism development: Evidence from Tra Vinh province, Vietnam. Asian Journal of Empirical Research, 8(2), 38-50.

(C) 2018 Asian Economic and Social Society. All rights reserved 


\section{INTRODUCTION}

From Chili (2015), the standard of sustainable development should apply to all the fields of the social development, even though it is social, political or economic development. Sustainable development is a new notion defining a development of all aspects of the current society, while sustaining the future generations' ability being still able to continue to satisfy their needs. More clearly, it can define sustainable development as a multidimensional concept consisting of different facets in a unified entity, a harmonious developmental structure, a natural or contradictory relationship. In addition, sustainable development is considered as a development that better meets the present needs of humankind and improves the quality of life of the current generation as well as of the future generations. Krajnc and Glavic (2005) develop the sustainable development model based on the basis of scientific, objective and quantitative calculations. The integrated impacts and development trends of three economic, socio-cultural and environmental key aspects have been demonstrated through a system of development indicators for each sector and locality in each nation, also known as the sustainable development triangle, as presented in Figure 1.

For many nations, especially developing economies, the tourism industry is one of the key important economic sectors for both national and local economic development, drawing both foreign and domestic visitors to the locality (Luu 2011; Bhuiyan et al. 2012). Therefore, a lot of governments pay special attention to tourism development (Homsud and Promsaard, 2015). Tourism is a competitive and dynamic sector needing a constant adaptation to tourists' increasing demands, satisfying the tourists' as well as local residents' requirements. However, for Cevirgen et al. (2012), tourism development in developing nations is still unsustainable. Those practices could affect the well-being and health of local community, the environment and the tourism itself, because tourism industries commonly impose negative influences on the socio-culture, the environment and also the economy. For long-term, therefore, the tourism industry should adopt sustainable development and should balance the three dimensions of the sustainable development triangle. According to Mingtai and Jinhuo (2007), sustainable tourism development refers to a tourism development that takes into account socio-cultural, economic and environmental respects. They also propose that an appropriate equilibrium should be set up between these three items to assure its stability.

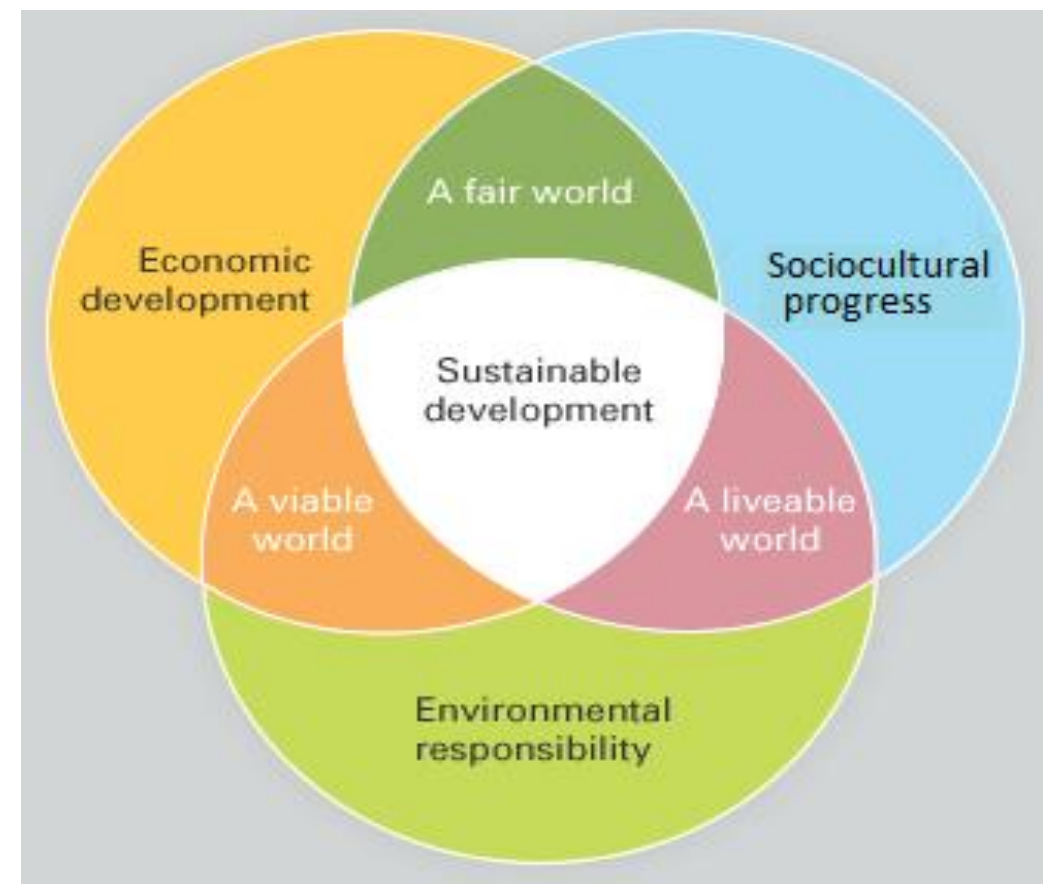

Figure 1: The sustainable development triangle 
The sustainability of tourism development is not only related to natural resource protection and conservation, but also constantly concerned with the local residents' well-being and perception (Bhuiyan et al., 2011). In addition, Ah-choy (2010) emphasizes that sustainable tourism development is a development focusing on environmental, environmental and socio-cultural aspects of tourism. The involvement of local residents is one of the most essential elements to ongoing tourism development because it is vital to the sustainability of tourism growth (see Muganda et al., 2013). Furthermore, numerous studies have confirmed that the perceptions and attitudes of host residents toward tourism development could affect the durability of the tourism industry as a consequence of the continuing tourism growth; for example economic changes (Simpson, 2008), environmental changes (Simpson 2008; Lee, 2013) and socio-cultural changes (Simpson, 2008; Lee et al. 2010). Tourism development is hard to obtain long-term sustainability without the support of local residents (Nicholas et al., 2009).

Cevirgen et al. (2012) suggest a causal relationship from local residents' perceptions of benefit and cost resulted from tourism to their supports to tourism development. Grasping the determinants of support to tourism development by local residents, especially a link between residents' perception and support to tourism development, is critical for the sustainability and success of tourism growth (Gursoy and Rutherford, 2004). These determinants can be the sustainability of tourism development according to the three sustainable dimensions. Drawing on Muganda et al. (2013), the existing management literature recommends a lot of roles local host residents can play in developing tourism industry. However, only a little literature offers an emphasis on local residents' behaviors or attitudes toward tourism development in the locality (e.g., satisfaction and support). Additionally, research on local residents' support to the sustainable development of tourism has been explored in developed countries. It is however still a hugely debated topic in developing countries, including Vietnam (Gursoy et al. 2009; Nicholas et al., 2009; Lai and Nepal, 2006). A little evidence, consequently, has been found on how local residents think of tourism development in these regions.

Furthermore, according to Tra Vinh province tourism development committee (2014), the local government is paying a special attention to the local development in tourism and trying to make it a key economic sector of the province, which will enhance joint socio-economic development in the local region. Tra Vinh province is a potential area of tourism development, which possesses a lot of favorable conditions in developing tourism. It is located between Tien and Hau rivers of Vietnam, so convenient for tourists to visit. In addition, Tra Vinh province owns the man-made and natural resources suitable to tourism development. Therefore, it is promising to become attractive attractions to local and foreign tourists.

Although Tra Vinh province's tourism industry recently has grown fast, tourism activities there have developed unsustainably (Nguyen and Vu, 2011). Therefore, in order for Tra Vinh province to sustainably develop its tourism industry, it is necessary to carry out studies related to the sustainable tourism development there. To fill that void, the current research tries to develop a hypothetical research model to explore the causal relationships among local residents' satisfaction and support to tourism growth and their perceived sustainability of tourism development with the data collected in Tra Vinh province, Vietnam.

\section{THEORETICAL FRAMEWORK}

This research develops a research model relating local residents' attitude and support to tourism development that discusses how local residents' satisfaction and perceived sustainability relate to their support for local tourism development. Sustainability should be comprehensively discussed for tourism development; because sustainable tourism development could satisfy the requirement of tourists, protect natural environment, offer opportunities to augment the local economy and enhance the life quality for local communities while maintaining chances for the future generations (Eagles et al., 2002). Research on tourism development highlights tourism development based on local community as a critical device for sustainable economic development (Taylor, 1995; Sebele, 2010). 
The current research employs social exchange theory to evaluate the attitudes of local residents towards tourism development, which are represented by local residents' satisfaction and support (Ko and Stewart, 2002). Based on Ekeh (1975), social exchange theory is grounded on the sociological and social psychological viewpoint to explicate social change and steadiness as a course of compromised exchanges among stakeholders. For Emerson (1976), social exchange theory suggests human relationships by using the analysis of subjective benefit-cost and the alternatives assessment. Lee (2013) takes the viewpoint of social exchange theory to confirm that the support of local residents for the development of tourism is reliant on their perception of tourism development by assessing environmental, socio-cultural and economic sustainability. When local residents weigh benefits from tourism development over incurred costs, they will satisfy and support tourism activities in their region. Much recent research has discussed and investigated the determinants of residents' support to the development of tourism; namely the perception on environmental, socio-cultural and economic impacts (Ko and Stewart, 2002; Oviedo-Garcia et al., 2008; Choi and Murray, 2010; Nunkoo and Ramkissoon, 2011; Lee, 2013) and residents' satisfaction with tourism development (Nunkoo and Ramkissoon, 2011; Assante et al., 2012; Wang et al., 2014; Homsud and Promsaard, 2015; Ko and Stewart, 2002).

A study by Ko and Stewart (2002) analyzes the effects of local residents' environmental, socio-cultural and economic perceptions on their satisfaction and support to tourism development. These scholars discover that satisfaction and support of local residents are positively interrelated with their perceived sustainability of tourism development (based on environmental, socio-cultural and economic respects); and local residents' satisfaction is a direct causation of their support to tourism development. Oviedo-Garcia et al. (2008) explore local residents' perceived sustainability of tourism development and prove environmental, socio-cultural and economic impacts as drivers of local residents' support to the development of tourism. The findings statistically evidence that perceptions of local residents on the sustainability and their support to the development of tourism are positively interdependent.

Choi and Murray (2010) apply social exchange theory to investigate a series of factors related to local residents' support for tourism development and their perceived sustainable tourism. Those academics highlight the role of local community in the sustainable development of tourism and confirm that the support of local residents for the development of tourism is positively determined by the sustainability of tourism development. Nunkoo and Ramkissoon (2011) rely on social exchange theory to analyze the research model of support by local residents to the development of tourism. The findings indicate that satisfaction of local residents and their perceived sustainability of tourism positively affect their support for the development of tourism. Residents' support to the development of tourism is an intricate matter, so it is necessary to take into consideration the attitudes of residents to tourism development before beginning projects related to tourism development. A study by Assante et al. (2012) concentrates on supporting attitudes and satisfaction of local residents to sustainable tourism development and argues that residential behavior is an important variable to the planning of tourism development because of the wise utilization of local resources to develop tourism. The results validate extremely strong effects of local residents' perceptions of the sustainability on their satisfaction and support to tourism development as well as a relationship between local residents' satisfaction and support.

Lee (2013) finds out that local residents' perceived costs and benefits impact their support to the development of tourism in which the perceived costs negatively affect the advocating of local residents to the development of tourism. In contrast, the perceived benefits are positively related to residents' support to the development of tourism. That researcher relies on social exchange theory to conclude that local residents' perceived costs and benefits of tourism are essential preceding variables of their support to tourism development, and so emphasizes the links of the perceived benefits and costs with the support of host community to the promotion of tourism and the model of tourism development based on local community. Wang et al. (2014) stress local residents' satisfaction of tourism development as one of the core stakeholders in developing tourism as well as alleviating poverty. The research reveals that the perceived costs and benefits are key antecedents of the satisfaction of local 
residents with tourism development. Therefore, tourism development should take into account the costs and benefits of tourism development perceived by local residents.

Homsud and Promsaard (2015) develop a research model of tourism development based on local residents' support and examine the links among local residents' perceived sustainability, their satisfaction and support to the development of tourism. The sustainability of tourism development is measured on environmental, economic and socio-cultural dimensions. The perceived sustainability is evidenced as a precedent of local residents' satisfaction with the development of tourism that in turn positively relates to residential support for the development of tourism. Moreover, that scholar underlines an important contribution of local residents' satisfaction to their support to tourism development because of its imperative role in attaining the sustainable development of tourism.

Much previous research has been to investigate the relationships among local residents' perceived sustainability and their support to tourism development, but just a few has evaluated the links between local residents' satisfaction and tourism development (Ko and Stewart, 2002). Further, Woo et al. (2015) emphasize the important role of local residents' satisfaction on their support to tourism development. Accordingly, an assessment of the linkage between local residents' satisfaction and their perception of tourism sustainability is a vital area of research in which the interrelation between the support of host residents to the development of local tourism and their perceived sustainability of tourism becomes clearer through residential satisfaction. Although various tourism academics have suggested the perceived costs and benefits as the intervenient variables in the relationships of the support to tourism development with community attachment as well as with environmental attitude; the mediating role of local residents' satisfaction in the research model has hardly been discussed and explored (Lee, 2013). It is consequently valuable to observe this relationship. This research uses social exchange theory based on the viewpoint of the development of tourism to analyze the research model of tourism. Social exchange theory recommends that the perception of local residents on the impacts of tourism development on their local region can influence their satisfaction with the development of tourism and then leading to their support to the development of tourism in the local community (Andereck et al., 2005). Clearly, local residents' perceived sustainability is an antecedent deciding their satisfaction with tourism development that in turn results in their support to tourism development in the local area. Numerous scholars reveal that local residents likely satisfy with local tourism development if they perceived a positive sustainability of tourism development, so they will support the activities of tourism development in their community (Gursoy and Rutherford, 2004). Grounded on the previously mentioned perspectives of social exchange theory, it can propose the mediating role of local residents' satisfaction in their support to the development of tourism. Understanding the satisfaction and support of local residents to the development of tourism is decisive to the efficient management of sustainable tourism development. Consequently, this research drawing upon the above mentioned perspectives to propose the following hypotheses:

H1: Economic, environmental and socio-cultural sustainability positively affects local residents' satisfaction with tourism development

H2: Local residents' satisfaction positively impacts on their support to tourism development

.H3: Economic, environmental and socio-cultural sustainability positively influences local residents' support to tourism development

H4: Local residents' satisfaction mediate the links between economic, environmental and sociocultural sustainability and their support to tourism development

\section{RESEARCH METHOD}

\subsection{Measurement instruments}

Based on a comprehensive literature review of sustainable tourism, a survey instrument was constructed for the analyses. The survey questionnaire consisted of items measuring perceived sustainability of tourism development, satisfaction of local residents with tourism development and support of local residents to tourism development. The scales of these variables were based on those 
in previous studies (e.g., Nunkoo and Ramkissoon, 2011; Assante et al., 2012; Lee, 2013; Ghanian et al., 2014; Homsud and Promsaard, 2015; Zamfir and Corbos, 2015). Perceived sustainability of tourism development consists of three dimensions: 1) Economic sustainability with 8 items; 2) Environmental sustainability with 7 items; 3) Socio-cultural sustainability with 8 items. Satisfaction of local resident with tourism development encompasses five items; whereas Support of local resident to tourism development is composed of seven items.

\subsection{Sample and data collection}

This research employed a convenience sampling to collect the data. This technique is a statistical method of collecting the data by selecting informants due to their availability and easy access. The 500 local permanent residents living around key tourism attractions in Tra Vinh province were selected for this work (Hair et al., 2009). This research selected only one person in one of the targeted holdhouses. In-person interviews with the informants were conducted. Finally, of the 500 answered questionnaires, only 363 responses provided sufficient information for the data analyses, achieving a usable response rate of $90.75 \%$. This number satisfies a minimum required sample size of 350 (Hair et al., 2009).

Before evaluating the measurement and structural models, the consistency and stability of observed items within their respective factors were evaluated by using a reliability analysis. Cronbach's Alphas were applied to assess the inter-consistency of the five factors in the research model of sustainable tourism development. For the 35 items, the corrected item-total correlations ranged from 0.597 to 0.843 (Table 1), which satisfied the critical level of 0.5 suggested by Hair et al. (2009). The Cronbach's Alphas varied from 0.871 to 0.931 , which were more than 0.7 , the proposed lowest limit (Hair et al., 2009). It can be therefore concluded that the observed variables in the research model were reliable in explaining their own constructs. In order words, the observed items obtained an internal consistency with their factors.

\section{Table 1: Reliability analysis}

\begin{tabular}{lccc}
\hline Constructs & $\begin{array}{c}\text { Number of } \\
\text { items }\end{array}$ & $\begin{array}{c}\text { Corrected item-total } \\
\text { correlations }\end{array}$ & $\begin{array}{c}\text { Alpha } \\
\text { value }\end{array}$ \\
\hline Economic sustainability & 8 & $0.620 \rightarrow 0.813$ & 0.909 \\
Environmental sustainability & 7 & $0.737 \rightarrow 0.836$ & 0.931 \\
Socio-cultural sustainability & 8 & $0.649 \rightarrow 0.843$ & 0.930 \\
Satisfaction of local resident & 5 & $0.622 \rightarrow 0.756$ & 0.871 \\
Support of local resident & 7 & $0.597 \rightarrow 0.798$ & 0.899 \\
\hline
\end{tabular}

\subsection{Data analysis}

This study conducted a reliability analysis to test the properties between constructs and their items. It then carried out a confirmatory factor analysis to check construct validity. This procedure also tests whether the hypothetical measurement model fits the analyzed data.

Furthermore, interrelations among the main independent variables are analyzed for the multicollinearity in the collected data. A structural equation modeling analysis is then applied to verify causal relationships in the structural model. This research finally uses a mediating method suggested in Goodman (1960) to statistically explore the mediating effect of local residents' satisfaction on the relationships of economic, environmental and socio-cultural sustainability with their support to tourism development.

\section{FINDINGS}

\subsection{Measurement model}

The measurement model was tested by using a confirmatory factor analysis, which classifies observed variables to their own constructs. Several indicators were applied to evaluate the goodness of fit of the research model (Byrne, 1991; Hu and Bentler, 1999; Hair et al., 2009). 
Table 2: Measurement model

\begin{tabular}{|c|c|c|c|}
\hline $\begin{array}{l}\text { Variables } \\
\end{array}$ & Loadings & AVE & $\mathbf{C R}$ \\
\hline Economic sustainability (ECS) & & 0.566 & 0.912 \\
\hline Tourism creates more jobs for local residents & 0.803 & & \\
\hline Tourism increases small business opportunities & 0.726 & & \\
\hline Tourism improves the infrastructure around the tourist destinations & 0.656 & & \\
\hline Tourism increases the revenues from tourists for local governments & 0.741 & & \\
\hline Tourism diversifies the local economy & 0.718 & & \\
\hline Tourism generates new resources of income for local residents & 0.697 & & \\
\hline Tourism increases markets for local producers & 0.792 & & \\
\hline Tourism attracts outside investment at locality & 0.863 & & \\
\hline Environmental sustainability (ENS) & & 0.662 & 0.932 \\
\hline Tourists consume more water than local residents & 0.864 & & \\
\hline Tourism increases the environmental pollution & 0.844 & & \\
\hline Tourists leave more litter than local residents & 0.801 & & \\
\hline Tourists creates more waste water than local residents & 0.772 & & \\
\hline Tourism threatens drinking water resources at locality & 0.837 & & \\
\hline Tourism overdevelopment destroys the living environment & 0.793 & & \\
\hline Tourism raises traffic problems & 0.778 & & \\
\hline Socio-cultural sustainability (SOS) & & 0.627 & 0.929 \\
\hline Tourism stimulate the preservation of local culture & 0.901 & & \\
\hline Tourism promotes cultural activities by local community & 0.788 & & \\
\hline Tourism improves standard of living for local residents & 0.643 & & \\
\hline $\begin{array}{l}\text { Tourism fosters cultural exchanges between tourists and local } \\
\text { residents }\end{array}$ & 0.820 & & \\
\hline Tourism imposes positive impacts on locally cultural identity & 0.880 & & \\
\hline Tourism increases the quality of local life & 0.690 & & \\
\hline Tourism positively affects the life of local residents & 0.749 & & \\
\hline $\begin{array}{l}\text { Tourism improves understanding between tourists and local } \\
\text { residents }\end{array}$ & 0.826 & & \\
\hline Satisfaction of local resident (SAT) & & 0.581 & 0.873 \\
\hline I am really satisfied with tourism development in my community & 0.760 & & \\
\hline I am fond of the interaction with tourists & 0.691 & & \\
\hline I really like to see increased numbers of tourists in my community & 0.721 & & \\
\hline $\begin{array}{l}\text { I am willing to participate in planning tourism development in my } \\
\text { community }\end{array}$ & 0.805 & & \\
\hline $\begin{array}{l}\text { Tourism makes the governmental departments pay more attention to } \\
\text { my community }\end{array}$ & 0.823 & & \\
\hline Support of local resident (SUP) & & 0.566 & 0.901 \\
\hline I support tourism development in my community & 0.841 & & \\
\hline $\begin{array}{l}\text { I am interested in activities related to tourism development in my } \\
\text { community }\end{array}$ & 0.718 & & \\
\hline $\begin{array}{l}\text { I would like to participate in cultural exchanges between tourists } \\
\text { and local residents }\end{array}$ & 0.650 & & \\
\hline $\begin{array}{l}\text { I care about decisions relevant to tourism development in my } \\
\text { community }\end{array}$ & 0.805 & & \\
\hline $\begin{array}{l}\text { I believe tourism development is getting more sustainable in my } \\
\text { community }\end{array}$ & 0.765 & & \\
\hline $\begin{array}{l}\text { I think the sustainability of tourism development in my community } \\
\text { is increasing }\end{array}$ & 0.786 & & \\
\hline $\begin{array}{l}\text { In my opinion, the local government, tourism companies, local } \\
\text { residents and tourists are increasingly aware and support sustainable } \\
\text { tourism development }\end{array}$ & 0.683 & & \\
\hline
\end{tabular}


The results of the confirmatory factor analysis indicated that the chi-square/degree of freedom achieves 1.992 greater than the acceptable cutoff value of 2 for the goodness of fit of the measurement model. The Root Mean Square Error of Approximation of 0.052 is below the acceptable level of 0.07. The Tucker-Lewis index of 0.932, the Goodness of fit index of 0.901, the Comparative fit index of 0.937 and the Incremental fit index of 0.938 were in excess of 0.9 , the minimum threshold. Overall, these fit indices reveal a goodness of fit of the measurement model to the analyzed data.

Table 2 presents factor loadings, average variance extracted estimates (AVEs) and composite reliability indices (CRs). A factor loading is the association of each observed item with its latent factor. An average variance extracted estimate is calculated on the mean percentage of variation in the latent factor represented by the observed items. A composite reliability index is the amount of the squared loadings divided by the sum of that amount and the amount of the error variations for the observed items. The factor loadings varied from 0643 through 0.901 , which are greater than the acceptable threshold of 0.5 (Hair et al., 2009). These loadings are all statistically significant at levels less than $1 \%$. These numbers offer evidence of high reliability. The average variance extracted estimates ranged from 0.566 through 0.662 , which are all more than the acceptable limit of 0.5 (Hair et al., 2009). The composite reliability indices took the numbers from 0.873 to 0.932 , greater than 0.7 , the lowest level stipulated by Hair et al. (2009). These high values reflect the adequate reliability of the factors. It could be concluded the measurement model attain a sufficient validity of convergent. Furthermore, the average variance extracted estimates were all larger than their respective squared correlations (Tables 2 and 3), indicating that the measured items have more in common with their own constructs than the other constructs. This finding statistically supports the validity of discriminant.

Table 3: Matrix of correlations and squared correlations

\begin{tabular}{llllll}
\hline & ECS & ENS & SOS & SAT & SUP \\
\hline ECS & 1.000 & 0.678 & 0.447 & 0.466 & 0.599 \\
ENS & 0.460 & 1.000 & 0.533 & 0.494 & 0.599 \\
SOS & 0.200 & 0.284 & 1.000 & 0.581 & 0.620 \\
SAT & 0.217 & 0.244 & 0.338 & 1.000 & 0.567 \\
SUP & 0.312 & 0.359 & 0.384 & 0.321 & 1.000 \\
\hline
\end{tabular}

Below the diagonal are squared correlations

Above the diagonal are correlations

Table 3 also provides statistical evidence of having no multicollinearity within the research model. Multicollinearity within the sample data is statistically tested based on correlations between the main independent constructs. A largest limit of correlations for no multicollinearity is suggested by Kennedy (1992) not to exceed the cutoff value of 0.8 . The correlations between economic sustainability, environmental sustainability, socio-cultural sustainability and satisfaction of local resident took the numbers from 0.447 through 0.678 (Table 3 ); so it can conclude that there is no multicollinearity occurring within the research model.

\subsection{Structural model}

The structural model was tested by using a structural equation modeling analysis. This procedure consists of a diverse set of mathematical algorithms and statistical techniques, which fit systems of factors to data. The structural model in this research hypothesized that there were causal effects of economic, environmental and socio-cultural sustainability on local residents' satisfaction with tourism development and on their support to tourism development, which is in turn determined by local residents' satisfaction with tourism development.

Various statistical indicators were employed to assess the goodness of fit of the structural model (Byrne, 1991; Hu and Bentler, 1999; Hair et al., 2009). The results of the structural equation modeling analysis showed that the chi-square/degree of freedom was 1.992, the Root Mean Square Error of Approximation was 0.052, the Tucker-Lewis index was 0.932, the Goodness of fit index was 0.901, 
the Comparative fit index was 0.937 and the Incremental fit index was 0.938 . These fit indicators provide a goodness of fit of the structural model to the sample data.

The regression coefficients from the structural model are listed in Table 4. The coefficients of economic, environmental and socio-cultural sustainability on local residents' satisfaction with tourism development took on the values of $0.181,0.163$ and 0.361 at the significance levels of $5 \%, 5 \%$ and $1 \%$ respectively. These statistics offer support for Hypothesis 1 . Perceived economic, environmental and socio-cultural sustainability positively affects local residents' satisfaction with tourism development.

The regression estimates of economic, environmental and socio-cultural sustainability on local residents' support to tourism development achieved the values of $0.208,0.244$ and 0.285 at the significance levels of $1 \%$ respectively. These results provide statistical evidence for Hypothesis 3 . Perceived economic, environmental and socio-cultural sustainability positively influences local residents' support to tourism development. Table 4 also offers an influential coefficient of 0.211 from local residents' satisfaction with tourism development to their support for tourism development at the $1 \%$ significance level. Hence, Hypothesis 2 is statistically supported.

\section{Table 4: Regression coefficients}

\begin{tabular}{llcccc}
\hline Causal linkages & & & Coefficients & S.E. & P \\
\hline SAT & $<---$ & ECS & 0.181 & 0.072 & $* *$ \\
SAT & $<---$ & ENS & 0.163 & 0.079 & $* *$ \\
SAT & $<---$ & SOS & 0.361 & 0.052 & $* * *$ \\
SUP & $<---$ & ECS & 0.208 & 0.070 & $* * *$ \\
SUP & $<---$ & ENS & 0.244 & 0.076 & $* * *$ \\
SUP & $<--$ & SOS & 0.285 & 0.053 & $* * *$ \\
SUP & $<--$ & SAT & 0.211 & 0.064 & $* * *$ \\
\hline
\end{tabular}

$* * *$ Significance at $1 \%$

$* *$ Significance at $5 \%$

\subsection{Mediating effect}

The results obtained from the structural equation modeling analysis indicated the direct effects of economic, environmental and socio-cultural sustainability on local residents' support to tourism development were $0.208,0.244$ and 0.285 respectively and the indirect effects were $0.038,0.034$ and 0.076 respectively. Consequently, the total effects of economic, environmental and socio-cultural sustainability on local residents' support to tourism development were $0.246,0.278$ and 0.361 respectively. These results propose that the relationships between the support of local residents to the development of tourism and their perceived socio-cultural, economic and environmental sustainability can be mediated by local residents' satisfaction with tourism development. Nonetheless, the structural equation modeling analysis does not provide any techniques to statistically test the significance for indirect effects through mediating mechanisms.

Table 5: Mediating effects

\begin{tabular}{llc}
\hline Mediator & Causal links & tindirect \\
\hline \multirow{3}{*}{ SAT } & ECS on SUP & $2.059^{* *}$ \\
& ENS on SUP & $1.809^{*}$ \\
& SOS on SUP & $3.004^{* * *}$ \\
\hline
\end{tabular}

$* * *$ Significance at $1 \%$

**Significance at $5 \%$

**Significance at $10 \%$ 
This study applied a mediating procedure proposed in Goodman (1960) to statistically investigate the mediating effect of local residents' satisfaction on the relationships of economic, environmental and socio-cultural sustainability with their support to tourism development. This method employs a t-test to test the significance of indirect effects. The outcomes were exhibited in Table 5. The t-statistics of the indirect effects of economic, environmental and socio-cultural sustainability on local residents' support to tourism development through their satisfaction with tourism development obtain the values of 2.059, 1.809 and 3.004 at significance levels of 5\%, $10 \%$ and $1 \%$ respectively. Based on these results, it could be concluded that local residents' satisfaction with tourism development statistically mediates the relationships between the support of local residents to the development of tourism and their perceived socio-cultural, economic and environmental sustainability. Hence, Hypothesis 4 was statistically supported. Having included into the research model of tourism development in consideration, local residents' satisfaction with tourism development will lessen the links between the support of local residents to the development of tourism and their perceived socio-cultural, economic and environmental sustainability.

\section{DISCUSSIONS AND CONCLUSION}

Sustainable tourism development has been interested in many countries, especially developing ones. The main aim of the current study was to explore the research model of sustainable tourism development. This research model investigates the role of local residents' satisfaction in developing sustainable tourism in Tra Vinh, a province of Vietnam as a developing country. The findings of this study further statistical evidence to consolidate the relationships among perceived economic, environmental, socio-cultural sustainability, local residents' satisfaction and their support to tourism development.

This research contributes to the extant tourism literature into the relationships among local residents' satisfaction and their support to tourism development with perceived sustainability of tourism. The primary objective was to study the mediating effect of local residents' satisfaction on the relationship between their support to tourism development and perceived sustainability, focusing on economic, environmental and socio-cultural sustainability. This research evidenced that the effect of perceived sustainability of tourism on local residents' support for tourism development is dependent on their satisfaction with tourism development. This mediating influence of satisfaction in sustainability demonstrates that local residents' satisfaction with local tourism development leads to their support to tourism activities in the locality, if they perceived a positive sustainability of tourism development (Andereck et al., 2005; Gursoy and Rutherford, 2004). Hence, this research highlights the importance of local residents' positive perception on the sustainability of tourism development in which it could enhance tourism development satisfaction of local residents and so improve their support to local tourism development.

This research also provided some managerial implications. Local residents' perceived economic, environmental and socio-cultural sustainability has been suggested as a precedent of their satisfaction and support to tourism (Nunkoo and Ramkissoon, 2011; Lee, 2013; Woo et al., 2015; Ko and Stewart, 2002). Nonetheless, each dimension of perceived economic, environmental and socio-cultural sustainability has been assessed in separate research models. This research integrated the three dimensions of economic, environmental and socio-cultural sustainability in a joint research model, together with local residents' satisfaction and support to tourism development. The findings found that socio-cultural sustainability is the most important determinants of local residents' satisfaction as well as their support to tourism development. This means that local residents are most concerned about socio-cultural problems arising from tourism development, then about economic and environmental problems. The results also indicated that local residents, who are more satisfied with tourism activities, will give more support to tourism development. Consequently, tourism managers should pay more attention to tourism satisfaction of local community, because it is one of the key agents affecting local tourism development. And the tourism managers need to take note of economic, environmental and socio-cultural sustainability, when participate in tourism development activities; especially take more 
note of socio-cultural sustainability because it most affects local residents' attitude toward tourism development.

Funding: This research has been financed by Tra Vinh department of science and technology, Tra Vinh
province, Vietnam.
Competing Interests: The author declares that s/he has no competing interest.
Contributors/Acknowledgement: The current project has been financed with a Research Grant from Tra
Vinh department of science and technology, Tra Vinh province, Vietnam. The author is very grateful to the
respondents for their help in providing essential information for the research analyses. The author also confirms
all the contribution for this paper being himself made and declares no conflict of interest with it.
Views and opinions expressed in this study are the views and opinions of the authors, Asian Journal of
Empirical Research shall not be responsible or answerable for any loss, damage or liability etc. caused in
relation to/arising out of the use of the content.

\section{References}

Ah-choy, E. (2010). The nascent development of ecotourism in Lagong Hill. American Journal of Applied Sciences, 7(12), 1528-1531. view at Google scholar / view at publisher

Andereck, K. L., Valentine, K. M., Knopf, R. C., \& Vogt, C. A. (2005). Residents' perceptions of community tourism impacts. Annals of Tourism Research, 32(4), 1056-1076. view at Google scholar / view at publisher

Assante, L. M., Wen, H. I., Lottig, K., \& Hotels, S. (2012). An empirical assessment of residents' attitudes for sustainable tourism development: A case study of Oahu, Hawaii. Journal of Sustainability and Green Business, 1(1), 1-27. view at Google scholar / view at publisher

Bhuiyan, M. A. H., Chamhuri, S., Shaharuddin, M. I., \& Rabiul, I. (2012). Home stay accommodation for tourism development in East coast economic region. American Journal of Applied Sciences, 9(7), 1085-1090. view at Google scholar / view at publisher

Bhuiyan, M. A. H., Siwar, C., Ismail, S. M., \& Islam, R. (2011). The role of home stay for ecotourism development in east coast economic region. American Journal of Applied Sciences, 8(6), 540546. view at Google scholar / view at publisher

Byrne, B. M. (1991). The Maslach Burnout Inventory: validating factorial structure and invariance across intermediates, secondary, and university educators. Multivariate Behavioral Research, 26(4), 583-605. view at Google scholar / view at publisher

Cevirgen, A., Baltaci, F., \& Oku, O. (2012). Residents' Perceptions towards Sustainable Tourism Development: The Case of Alanya. 3rd International Symposium on Sustainable Development, 65-76, Sarajevo, Bosna nd Hercegovina. view at Google scholar / view at publisher

Chili, N. S. (2015). Perceptions and attitudes of the community towards tourism impacts and sustainable development: The case study of eMpophomeni in Pietermaritzburg (South Africa). Problems and Perspectives in Management, 13(3-1), 151-159. view at Google scholar

Choi, H. C., \& Murray, I. (2010). Resident attitudes toward sustainable community tourism. Journal of Sustainable Tourism, 18(4), 575-594. view at Google scholar / view at publisher

Eagles, P. F. J., McCool, S. F., \& Haynes, C. F. (2002). Sustainable tourism in protected areas: Guidelines for planning and management. Gland, Switzerland: International Union for the Conservation of Nature. view at Google scholar

Ekeh, P. P. (1975). Social exchange theory: the two traditions. Canadian Journal of Sociology, 1(3), 394-396. view at Google scholar / view at publisher

Emerson, R. M. (1976). Social exchange theory. Annual review of sociology, 2(1), 335-362. view at Google scholar / view at publisher

Ghanian, M., Ghoochani, O. M., \& Crotts, J. C. (2014). An application of European performance satisfaction index towards rural tourism: The case of western Iran. Tourism Management Perspectives, 11(1), 77-82. view at Google scholar / view at publisher

Goodman, L. A. (1960). On the exact variance of products. Journal of the American Statistical Association, 55(292), 708-713. view at Google scholar / view at publisher

Gursoy, D., Chi, C. G., \& Dyer, P. (2009). An examination of locals' attitudes. Annals of Tourism Research, 36(4), 723-726. view at Google scholar / view at publisher 
Gursoy, D., \& Rutherford, D. G. (2004). Host attitude toward tourism: An improved structural model. Annals of Tourism Research, 31(3), 495-516. view at Google scholar / view at publisher

Hair, J. F., Black, W. C., Babin, B. J., Anderson, R. E., \& Tatham, R. L. (2009). Multivariate data analysis. New Jersey: Pearson Prentice Hall, USA. view at Google scholar

Homsud, N., \& Promsaard, S. (2015). The effects of residents' image and perceived tourism impact to residence satisfaction and support: A case study of Hua-Hin Prachubkirikhan. The 2015 WEI International Academic Conference Proceedings, Vienna, Austria. view at Google scholar / view at publisher

Hu, L., \& Bentler, P. M. (1999). Cutoff criteria for fit indexes in covariance structure analysis: Conventional criteria versus new alternatives. Structural Equation Modeling: A Multidisciplinary Journal, 6(1), 1-55. view at Google scholar / view at publisher

Ko, D. W., \& Stewart, W. P. (2002). A structural equation model of residents' attitudes for tourism development. Tourism Management, 23(5), 521-530. view at Google scholar / view at publisher

Kennedy, P. (1992). A guide to econometrics. 3rd ed. MIT Press, Cambridge, Massachusetts, USA. view at Google scholar

Krajnc, D., \& Glavic, P. (2005). A model for integrated assessment of sustainable development. Resources, Conservation and Recycling, 43(2), 189-208. view at Google scholar

Lai, P. H., \& Nepal, S. K. (2006). Local perspectives of ecotourism development in Tawushan Nature Reserve, Taiwan. Tourism Management, 27(6), 1117-1129. view at Google scholar / view at publisher

Lee, T. H. (2013). Influence analysis of community resident support for sustainable tourism development. Tourism Management, 34(1), 37-46. view at Google scholar / view at publisher

Lee, C. K., Kang, S. K., Long, P., \& Reisinger, Y. (2010). Residents' perceptions of casino impacts: a comparative study. Tourism Management, 31(2), 189-201. view at Google scholar / view at publisher

Luu, T. T. (2011). Corporate social responsibility and sustainable tourism. Business and Economic Research, 1(1), 1-9. view at Google scholar / view at publisher

Mingtai, L., \& Jihhuo, H. (2007). Issues and progress on tourism sustainable development appraisal research. Resource Development and Market, 2007(4), 319-322. view at Google scholar

Muganda, M., Sirima, A., \& Ezra, P. M. (2013). The role of local communities in tourism development: Grassroots perspectives from Tanzania. Journal of Human Ecology, 41(1), 5366. view at Google scholar / view at publisher

Nguyen, D. H., \& Vu, V. H. (2011). Sustainable tourism. Vietnam National University Publishing House, Hanoi- Vietnam. view at Google scholar

Nicholas, L., Thapa, B., \& Ko, Y. (2009). Residents' perspectives of a world heritage site- the Pitons Management Area, St. Lucia. Annals of Tourism Research, 36(3), 390-412. view at Google scholar

Nunkoo, R., \& Ramkissoon, H. (2011). Residents' satisfaction with community attributes and support for tourism. Journal of Hospitality and Tourism Research, 35(2), 171-190. view at Google scholar / view at publisher

Oviedo-Garcia, M. A., Castellano-Verdugo, M., \& Martín-Ruiz, D. (2008). Gaining residents' support for tourism and planning. International Journal of Tourism Research, 10(2), 95-109. view at Google scholar / view at publisher

Sebele, L. S. (2010). Community-based tourism ventures, benefits and challenges: Khama Rhino Sanctuary Trust, Central District, Botswana. Tourism Management, 31(2010), 136-146. view at Google scholar / view at publisher

Simpson, M. C. (2008). Community benefit tourism initiatives: a conceptual oxymoron? Tourism Management, 29(1), 1-18. view at Google scholar / view at publisher

Taylor, G. (1995). The community approach: does it really work? Tourism Management, 16(7), 487489. view at Google scholar / view at publisher

Tra Vinh provincial tourism development committee (2014). Solutions to develop Tra Vinh provincial tourism to year 2025. People's Committee of Tra Vinh province; Tra Vinh- Vietnam. view at Google scholar 
Wang, X., Zhen, F., Zhang, J., \& Wu, X. (2014). Exploring factors influencing residents' satisfaction with tourism development in poverty-stricken areas: A case study of five poor villages in China. Asia Pacific Journal of Tourism Research, 19(5), 517-537. view at Google scholar / view at publisher

Woo, E., Kim, H., \& Uysal, M. (2015). Life satisfaction and support for tourism development. Annals of Tourism Research, 50(2015), 84-97. view at Google scholar / view at publisher

Zamfir, A., \& Corbos, R. A. (2015). Towards sustainable tourism development in urban areas: case study on Bucharest as tourist destination. Sustainability, 7(9), 12709-12722. view at Google scholar / view at publisher 